\title{
The effect of L-Lysine in recurrent herpes labialis: pilot study with a 8-year follow up
}

O efeito da L-Lisina na herpes labial recorrente: estudo piloto com 8 anos de seguimento

\author{
Maria Cristina PEDRAZINI ${ }^{1}$ \\ (D) ORCID iD 0000-0002-7649-6626 \\ Vera Cavalcanti ARAÚJO2 \\ (iD) ORCID iD 000-0003-4087-889X \\ Victor Angelo Martins MONTALLI ${ }^{2}$ \\ (iD) ORCID iD 0000-0002-1927-7718
}

\begin{abstract}
Several treatments for recurrent herpes labialis have been tested, including intradermal snake venom, camphor compresses, psychiatric treatments, vitamin C and other vitamin complexes. Nowadays, topical and systemic retroviral drugs such as acyclovir, valacyclovir and vadarabina are the drugs of choice. However they are only effective for symptoms minimization of existing lesions, without eliminating the virus permanently. In this study an alternative treatment with oral L-lysine is presented. This is one of the eight essential not manmade amino acids which should be acquired through feeding since they are important for protein synthesis and organism development. It was observed a significant effect on the annual incidence reduction of recurrent herpes in 12 patients with 8-year follow up.
\end{abstract}

Indexing terms: Amino acids. Herpes labialis. Wounds and injuries.

\section{RESUMO}

Vários tratamentos para herpes labial recorrente foram testados, incluindo veneno de cobra intradérmica, compressas de cânfora, tratamentos psiquiátricos, vitamina C e outros complexos vitamínicos. Atualmente, as drogas retrovirais tópicas e sistêmicas, como o aciclovir, o valaciclovir e a vadarabina são as drogas de escolha. No entanto, eles são eficazes apenas para minimizar os sintomas das lesões existentes, sem eliminar o vírus permanentemente. Neste estudo é apresentado um tratamento alternativo com L-lisina oral. Este é um dos oito aminoácidos essenciais não fabricados pelo homem, que devem ser adquiridos através da alimentação, uma vez que são importantes para a síntese de proteínas e o desenvolvimento do organismo. Foi observado um efeito significativo na redução da incidência anual de herpes recorrente em 12 pacientes com 8 anos de seguimento.

Termos de indexação: Aminoácidos. Herpes labial. Ferimentos e lesões.

\section{INTRODUCTION}

The Herpes simplex virus, transmitted primarily by saliva, was firstly isolated in 1939 in children afflicted with herpetic gingivostomatitis. Fever, irritability, pain when swallowing, regional lymphadenopathy and several scattered ulcerated lesions on the oral mucosa, lip and nose are the symptoms usually presented [1].

During herpetic gingivostomatitis, the virus penetrates the peripheral sensory nerves and it migrates through the axons to regional sensory ganglia (trigeminal ganglion), where it remains in latency until it is disrupted by triggering factors such as immunosuppression [2], infections, excessive ultraviolet radiation (herpes solaris), stress, local trauma (traumatic herpes), hormonal changes in the menstrual period (herpes menstrualis) and fever (herpes febrilis) [3]. The virus then migrates to the skin and mucosa cells causing injuries and recurrent infections which are called secondary or recurrent herpetic gingivostomatitis or only herpes labialis.

The simple herpes labialis, in immunocompetent patients, evolves through 3 clinical periods of the disease. The first 24 hours before the disease manifestation is called latent or prodromal period (figure $1 \mathrm{~A}$ ). The active clinical

\footnotetext{
${ }^{1}$ Faculdade São Leopoldo Mandic, Curso de Odontologia, Departamento de Implantodontia. Rua Dr. José Rocha Junqueira, 13, 13045-755, Campinas, SP, Brasil. Correspondência para / Correspondence to: MC PEDRAZINI. E-mail: <mcpequipe@gmail.com>.

${ }^{2}$ Faculdade São Leopoldo Mandic, Curso de Odontologia, Departamento de Patologia Oral. Campinas, SP, Brasil.

$\boldsymbol{\nabla} \mathbf{v} \boldsymbol{\nabla}$

Como citar este artigo / How to cite this article

MC Pedrazini, VC Araújo, VAM Montalli. The effect of 1-lysine in recurrent herpes labialis - pilot study with a 8-year follow up. RGO, Rev Gaúch Odontol. 2018;66(3):245-249. http://dx.doi.org/10.1590/1981-863720180003000083517
} 
period is related to the appearance of the first papules remaining 2 to 4 days (figure $1 \mathrm{~B}$ ). At the end of the cycle reparatory period - the vesicles are reduced and remain, on average from 2 to 4 days (figure 2A), until final total repair (figure 2B) [4].

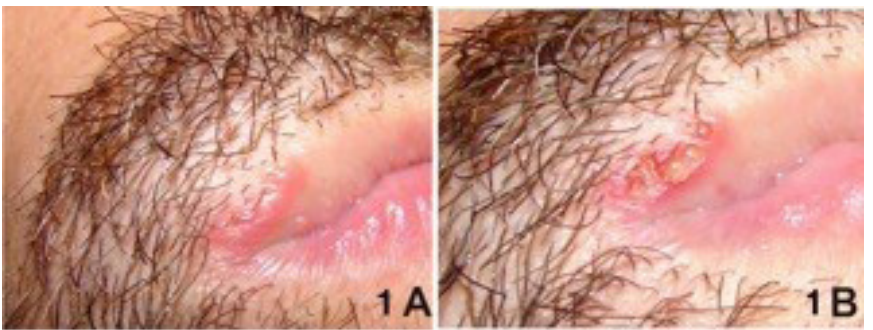

Figure 1. A) Injury in 12 hours - prodromal period; B) Injury in 72 hours -active clinical period.

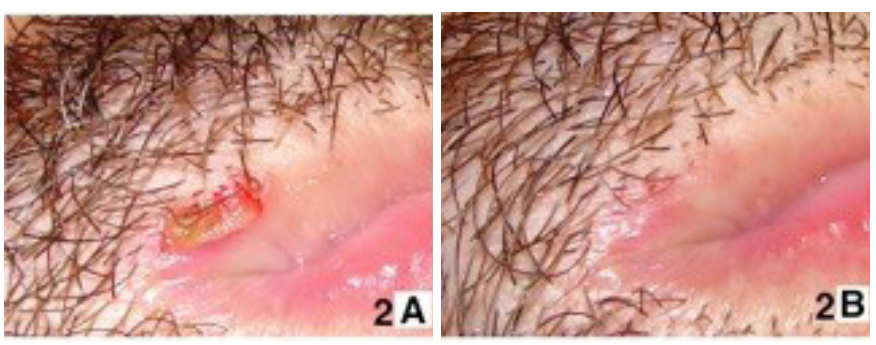

Figure 2. A) Injury in 6 days - reparatory period; B) B - Injury in 8 days - total repair.

The supplementation of L-lysine is safe. A $70 \mathrm{~kg}$ man may use 800-3000 mg / day. Doses of up to $3 \mathrm{~g}$ per day are well tolerated; however, higher doses (10-15g per day) can cause gastrointestinal disturbances, including nausea, abdominal cramps and diarrhea. Prophylactic L-lysine to patients with recurrent herpes range from $500-3000 \mathrm{mg} /$ day. A reasonable recommendation is $500-1000 \mathrm{mg}$ daily for prophylaxis, keeping higher doses (3,000 mg / day) for active outbreaks and only for a limited time to the acute phase [5-9].

L-Lysine, in particular, has a significant effect on reduction of virus replication HSV1 in animals [10] and it also reduces the healing time $[9,11]$. Studies have corroborated with the positive results of L-lysine showing a reduction in both, lesion cycles as in its incidence $[5,9,12-17]$.

A previous study indicted that after 12 months from the first cycle of L-lysine, an average reduction of $49 \%$ in time for the damage repair in one year and this reduction was statistically significant $(p<0.01)$. In one year, a decrease of $63 \%$ in the lesions incidence was observed and this reduction was statistically significant $(p<0.01)$. A paired $t$ test was used to compare the incidence and duration of the cycle before and after this first treatment [5].
The objective of this study was to show, through clinical observation, a significant effect on the annual incidence reduction of recurrent herpes in a 8-year follow up.

\section{METHODS}

This study was conducted upon the approval of the Ethical Committee of São Leopoldo Mandic Institute and Research Center (Protocol \# 12/0522) and with the consent forms signed by participants.

The prospective study was conducted in a group of 12 individuals, being five males and seven females aged between 30 and 48 years old, suffering from recurrent herpes labialis lesions with manifestations ranging from over one or more episode per month to one or more every three months.

All members belonged to the same socio-economic and cultural class and they had never received any systemic therapy prior to the study. Regarding the topical treatment, antiviral acyclovir cream were used three times a day since the first signal of the lesion.

Before starting treatment with L-Lysine, data were collected retrospectively from the last 12 months on the number of occurrences of lesions as well as the healing time of each lesion. The traced data were pooled to be compared.

The treatment was initiated with L-Lysine, manipulated in a single homoeopathic pharmacy, during the lesion crust phase using one capsule of $500 \mathrm{mg}$ daily for 30 days, taken fasting with water, one hour before a meal or two hours minimum after.

Patients were instructed to continue the use of the same acyclovir cream they were using prior to Lysine keeping a record of herpes episodes and their healing time within a year. The group was contacted every 2 months during the first year and data were collected. A new 30-day course of $500 \mathrm{mg}$ L-lysine was prescribed 12/12 months with the same dosing guidelines. Patients were instructed on how to control the triggering factors such as sun exposure and stress and dietary advice with a diet rich in L-Lysine as well as avoiding the consumption of foods rich in Arginine was prescribed. Monitoring was continued in the following years every 4 months and a data sheet with the number of annual injuries was completed.

\section{Statistical analysis}

A Friedman test was used for comparison of the repeated measures followed by Dunn's test and the results 
with $p<0.05$ were considered significant. All the statistical procedures were performed using GraphPad Prism version 6.0 for Mac (GraphPad Software® La Jolla, USA).

\section{RESULTS}

Since the first year using L-Lysine, all the patients informed a decrease of number of recurrent herpes labialis. The data showed that the annual number of injuries were similar in men and women (Table 1).

Table 1. Clinical aspects and annual incidence of injuries before and after L-Lysine cycle - 8-years follow up.

\begin{tabular}{lcccl}
\hline & \multicolumn{2}{c}{ Male $(n=5)$} & \multicolumn{2}{c}{ Female $(n=7)$} \\
\cline { 2 - 5 } & Mean (SD) & Min - Max & Mean (SD) & Min - Max \\
\hline Age & $41.4(6.0)$ & $32-48$ & $38.3(3.8)$ & $34-44$ \\
Lefore & $6.0(2.4)$ & $4-10$ & $8.6(3.2)$ & $5-12$ \\
Year 1 & $2.8(1.9)$ & $1-6$ & $2.7(1.7)$ & $1-6$ \\
Year 2 & $2.0(0.7)$ & $1-3$ & $2.0(1.0)$ & $1-4$ \\
Year 3 & $1.8(0.4)$ & $1-2$ & $1.7(1.1)$ & $1-4$ \\
Year 4 & $0.2(0.4)$ & $0-1$ & $0.3(0.5)$ & $0-1$ \\
Year 5 & $1.2(0.4)$ & $1-2$ & $1.7(1.0)$ & $0-3$ \\
Year 6 & $0.4(0.5)$ & $0-1$ & $0.3(0.5)$ & $0-1$ \\
Year 7 & $0.6(0.5)$ & $0-1$ & $0.7(1.0)$ & $0-2$ \\
Year 8 & $0.2(0.4)$ & $0-1$ & $0.1(0.4)$ & $0-1$ \\
\hline Legend: SD = standard deviation & & &
\end{tabular}

Some patients presented improvement in the occurrence of herpes with low intensity lesions compared to those of the outbreaks before the Lysine, as they also reported that many lesions did not evolve to the bullous phase disappearing even in the prodromal phase. All small demonstrations occurred due to unprotected excessive solar radiation, either for long periods of stress or after a large intake of peanuts.

The results of the evaluations are demonstrated in Table 1 and figure 3, considering the mean and standard deviation of lesions in a period of 8 years.

\section{DISCUSSION}

L-Lysine has the function, amongst others, of tissue repairing, since it stimulates growth while participating in the hormones synthesis. It also helps antibodies production explaining lesion cycle reducing time [11] and this fact supports this study once it showed an average reduction of $49 \%$ in these cycles.

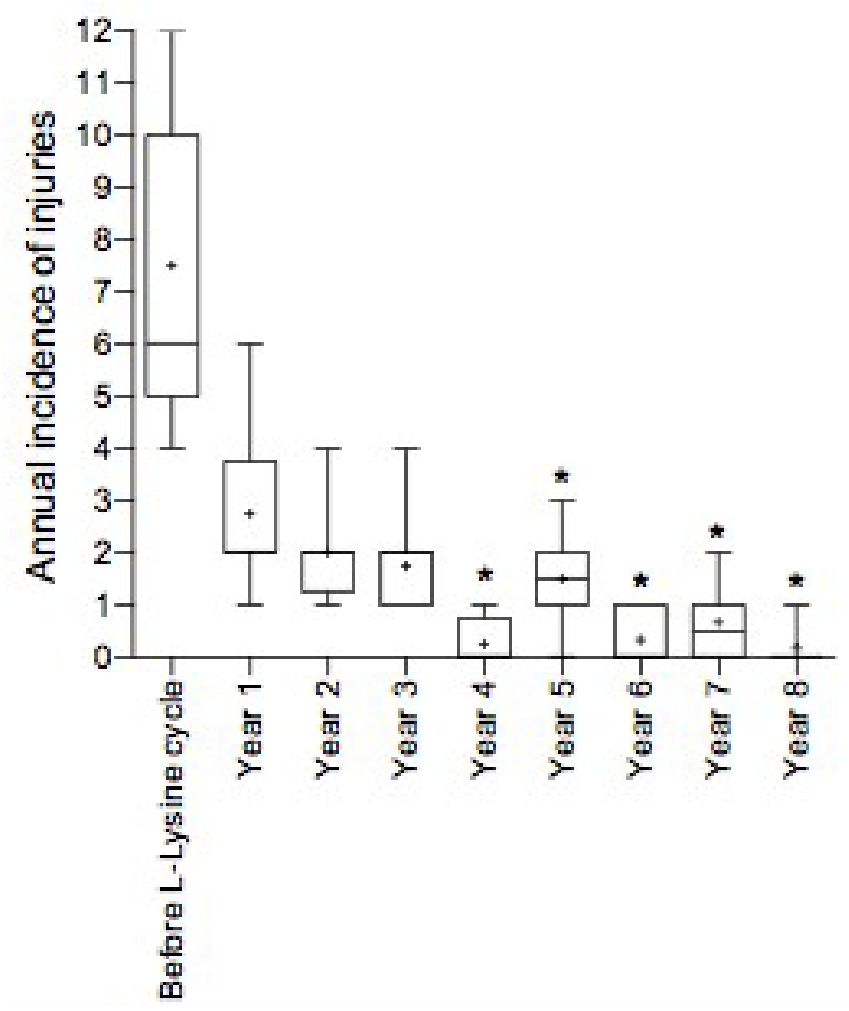

Figure 3. Graphical representation of annual incidence of injuries before and after L-Lysine cycle - 8-years follow up.

The amino acid lysine has an antagonistic relationship with the amino acid arginine which is an amino acid required for the replication of HSV virus [16]. This study shows that in the presence of L-Lysine, viral growth is inhibited $[10,13-14,16]$ thus explaining the reduction of $63 \%$ in the injuries incidence in the first year. Consequently, there was also a reduction of actions required during subsequent years of monitoring when there had been lysine supplementation for 30 days a year.

Some studies also supported the findings of this research, among them, a double blind controlled study with 27 patients who received $1000 \mathrm{mg}$ of lysine three times a day for six months. There was a reduction in the incidences of lesions $(p<0.05)$, a substantial reduction in symptom severity $(p<0.05)$ and a reduced healing time $(p<0.05)$ compared with the group receiving placebo treatment [12]. Another prospective study with 9 subjects receiving $500 \mathrm{mg}$ of lysine daily in conjunction with a diet low in arginine, showed reduction in recurrence, severity, and duration of lesions [13].

A multicenter study with 45 patients suffering from recurrent infections of HSV 1 where it was 
administered 320 to $1.200 \mathrm{mg} /$ day of Lysine for two months and also a restriction rich in arginine food was made. The results showed a reduction in infection recurrence while individuals were in treatment however when the treatment was discontinued, new lesions appeared between the first and fourth week [14]. Another group of 65 patients divided into a control group with placebo and the test group with $500 \mathrm{mg}$ of L-Lysine was monitored. In this study the authors observed a reduction in recurrence of lesions in the test group $(27.7 \%)$ and in the control group (12.3\%), p <0.05. The dose was equally administered twice a day for 12 weeks [15]. The efficacy of long-term prophylactic lysine supplementation was also examined in a group of 26 volunteers with a record of frequently recurring herpetic lesions. The double-blind crossovers study included an experimental group receiving daily oral supplements of 1,000 mg L-Lysine. Serum samples were analyzed at scheduled intervals. In most instances, members of the lysine group reported significantly fewer lesions in comparison to the control group. Similarly, those who were taken off lysine supplementation generally showed a significant increase in lesion occurrence. Quantitative hematologic measurements revealed the most clinically useful relationship. Data from this sample population indicated that when a person's serum lysine concentration exceeded $165 \mathrm{nmol} / \mathrm{ml}$ there was a corresponding significant decrease in recurrence rate. Conversely, the frequency rate increased significantly as concentration levels fell below $165 \mathrm{nmol} / \mathrm{ml}$. These results suggest that prophylactic lysine may be useful in managing selected cases of recurrent herpes simplex labialis if serum lysine levels can be maintained at adequate concentrations [17].

For disease prevention of herpes labials, foods rich in lysine like fish, milk, meat, cheese, soy, egg and brewer's yeast are recommended for virus carriers while food containing the amino acid arginine as nuts, gelatin, chocolate, raisins and popcorn should be avoided because they trigger the reappearance of herpes labialis [5].

Researches are still being developed with the aim of discovering the cure for cold sores, however until now the alternative therapeutic available only improve the patients' life quality by reducing the incidence of injuries. The L-Lysine amino acid used in this study is a natural product and has no side effects when prescribed in the right recommended doses. Lysine should be taken in fasting, since food undertakes the absorption. Among the advantages of this therapy, we can also cite the low cost and the short-term treatment protocol. Lysine showed positive results in reducing the incidence of recurrent lesions, and also in time to repair the lesions [5].

Efficacy was demonstrated, but randomized clinical trials in larger samples are needed to keep on researching in order to prove the effectiveness of this drug.

\section{CONCLUSION}

In the present study, it can be concluded that it is possible to alter the balance of the lysine-arginine in the body with increased intake of lysine and this contributes to the control of recurrent herpes labialis.

\section{Collaborators}

MC PEDRAZINI, researcher responsible for the methodology, data collection and the composition of the article. VC ARAUJO, researcher responsible for final revision of the article composition. VAM MONTALLI, researcher responsible for the statistical analysis and the final results composition.

\section{REFERENCES}

1. Siegel MA. Diagnosis and management of recurrent herpes simplex infections. J Am Dent Assoc. 2002 ;133(9):1245-9. doi: 10.14219/jada.archive.2002.0366

2. Boraks S. Diagnóstico bucal. São Paulo: Artes Médicas; 1996.

3. Bengel W, Veltman G. Differential diagnosis of diseases of the oral mucosa. Chicago: Quintessence Books; 1989.

4. Consolaro A, Consolaro MF. Diagnóstico e tratamento do herpes simples recorrente peribucal e intrabucal na prática ortodôntica. Rev Dent Press Ortodon Ortop Facial. 2009;14:16-24. doi: $10.1590 /$ S1415-54192009000300003

5. Pedrazini MC, Cury PR, Araujo VC, Wassall T. Efeito da lisina na incidência e duração das lesões de herpes labial recorrente. RGO, Rev Gaúch Odontol. 2007;55:7-10.

6. Marzzoco A, Torres BB. Bioquímica básica. $2^{\mathrm{a}}$ ed. Rio de Janeiro: Guanabara Koogan; 1999.

7. Meredith CN, Wen ZM, Bier DM, Matthews DE, Young VR. Lysine kinetics at graded lysine intakes in young men. Am J Clin Nutr. 1986;43(5):787-94. doi: 10.1093/ajcn/43.5.787

8. Duncan AM, Ball RO, Pencharz PB. Lysine requirement of adult 
males is not affected by decreasing dietary protein. Am J Clin Nutr. 1996;64(5):718-25. doi: 10.1093/ajcn/64.5.718

9. Roberts JJ, Solanki NS, Kurmis R, Lammerink S, Wong KL, Greenwood JEAM. Prophylaxis against herpes simplex virus reactivation in patients with facial burns: a-potential role for I-lysine. J Burn Care Res. 2013;34(6):368-9. doi: 10.1097/ BCR.0b013e3182685b59

10. Smirnova IP, Diorditse SV, Alekseev SB, Zaitsev IZ. Effect of L-Lysine-a-oxidase on reproduction of herpes simplex type 1 virus in vitro. Vopr Med Khim.1998;44(4):384-7.

11. Selishcheva AA, Alekseev SB, Smirnova IP, Podboronov VM. Antiherpetic Activity of L-Lysine-alpha-oxidase in different dosage forms. Antibiot Khimioter. 2003;48(1):9-12.

12. Griffith RS, Walsh DE, Myrmel KH, Thompson RW, Behforooz A. Success of L-lysine therapy in frequently recurrent Herpes simplex infection. Treatment and prophylaxis. Dermatologica. 1987;175(4):183-90.

13. Miller CS, Foulke CN. Use of lysine in treating recurrent oral Herpes simplex infections. Gen Dent. 1984;32:490-93.
14. Griffith RS, Norins AL, Kagan C. A multicentered study of lysine therapy in Herpes simplex infection. Dermatologica. 1978;156(5):257-67.

15. Milman N, Scheibel J, Jessen O. Lysine prophylaxis in recurrent Herpes simplex labialis: a double-blind, controlled crossover study. Acta Derm Venereol. 1980;60(1):85-7.

16. Griffith RS, DeLong DC, Nelson JD. Relation of argininelysine antagonism to Herpes simplex growth in tissue culture. Chemotherapy. 1981;27(3):209-13. doi: 10.1159/000237979

17. Thein DJ, Hurt WC. Lysine as a prophylactic agent in the treatment of recurrent herpes simplex labialis. Oral Surg Oral Med Oral Pathol. 1984;58(6):659-66.

Received on: 11/12/2017

Final version resubmitted on: 17/4/2018

Approved on: 25/6/2018 